\title{
Concluding Remarks by Dire Tladi
}

\author{
The Authoriy and the Membership of the Commission in the Future-Art, \\ Science and Economics: a Comment on Trávničková and Pinto
}

It is appropriate to enquire into the authority and membership of the International Law Commission as the Commission enters its seventh decade of existence. While the authority of the Commission has been a given for most of its existence, the passage of the golden years and the emergence of a new era when treaties developed by the Commission are becoming fewer, have led some to ponder whether the Commission still commands the respect and authority of yesteryear. Similarly, this new era, dominated as it is by notions of equity and equality, rightly forces us to confront the question of the composition or membership of the Commission.

These two themes, the "authority" and "membership" of the Commission, as well as the interaction between the two themes, are addressed in two different, but equally fascinating ways, in the papers by Mónica Pinto and $\mathrm{Zu}$ zana Trávníčková. In addressing the two themes of "authority" and "membership", both papers arrive at interesting conclusions about representation on the Commission. Particularly interesting observations were made about gender and geographic representation, generational distribution and professional representation. The two papers, presented during a panel chaired by former member of the Commission, Professor Momtaz, approached the subject of "The authority and membership of the Commission in the future", in quite distinct ways and arrived at very different conclusions. The written papers, submitted subsequently, provide further detail explanation on the themes and conclusions advanced by the Professors Pinto and Trávníčková.

In this short comment, I do not intend to respond to everything raised in these very interesting papers. I intend only to offer observations on the overarching themes and conclusions presented by the papers. In particular, while the papers cover a wide array of issues, I wish to focus only on those issues that directly touch on the two themes - authority and membership - and in particular their interaction. In the next section, the themes in the papers are explored, before some concluding remarks are made. In these concluding remarks I try to illustrate how these papers are an advert - an inadvertent campaign - for 
diversity of approaches and views. The conclusion also suggests that these two very divergent papers, that come to very divergent views about the authority and membership of the Commission, perhaps teach us that the truth is, as is often the case, somewhere in the middle.

I begin by a description of Zuzana Trávníčková's paper. She introduces her paper with a pedagogic slant - the presentation during the panel itself was centred around this pedagogic approach, illustrating how the Commission, and in particular this relationship, can provide a pair of binoculars through which to survey international law and its evolution for students. The presentation, and introduction of the written paper, has a literary feel to it. In her final written paper, Zuzana Trávníčková does not present us with the images of "beautiful temples somewhere in the mountains" and stories, stars, some not so bright, in the international law sky. While the paper begins with the pedagogic descriptions, with an artistic feel, it employs the metaphor of the market to describe the Commission's authority and membership and the interaction of these two themes. Zuzana Trávnícková considers the length of time it took to complete the articles on the responsibility of States for internationally wrongful acts, ${ }^{1}$ and observes, in very market, business-like language, that in any other business enterprise the State responsibility project would have been shelved as not being worth the investment. ${ }^{2}$

In her metaphor, Zuzana Trávníčková presents codification, in the broad sense including also progressive development, as a service on the market. Legitimacy and respect are the consideration given for the service. In this metaphor, the International Law Commission is a supplier of the service of codification and States are the consumers - Zuzana Trávníčková refers to these as demanders. She is at pains to point out that the International Law Commission is not the only provider of the service of the codification. In this sense, the codification of international law is subject to competition and the Commission is not "the monopoly". ${ }^{3}$ Other entities, such as the General Assembly itself, conferences convened under the auspices of the United Nations and the United

1 ILC, 'Articles on Responsibility of States for Internationally Wrongful Acts' UNGA Res 56/83 (12 December 2001), annex.

2 Zuzana Trávníčková, 'The International Law Commission and the International Law Codification Market', 363 , in this Section.

3 Ibid 358 . 
Nations Commission on International Trade Law are but examples of other forums where international law is codified - not listed, but certainly one of the more prestigious is the Institut de Droit international. ${ }^{4}$ These other forums are alternative service providers. But for the most part, with the notable exceptions of the General Assembly, these other service providers "can be classified by their scope of operation (their specialization ...), on one hand, and by their 'distance' from States, on the other hand".

The International Law Commission is different from these. If I were inclined towards the market metaphor employed by Zuzana Trávnícková - and I am not - I would describe the Commission as the dominant, luxury brand of the market. It would occupy the dominant positions of German car-brands like BMW or Mercedes Benz, or technology giants like Apple or Microsoft. Zuzana Trávníčková is much more conservative, describing the Commission's place on the market only as "firm, undisputable and also unique". ${ }^{6}$ What is more important is not so much how Zuzana Trávníčková describes the Commission's place in the market, but why it has this "firm, undisputable and [..] unique" position on the market - what I would refer to as a dominant position. She provides three reasons (answers), for the unique position. And it is these three reasons that lead Zuzana Trávníčková to address the representational issues which potentially affect the authority of the Commission and its place in the market of codification. The first reason for the uniqueness of the Commission as a service provider in the codification market is the authority that it commands. ${ }^{7}$ The second is its composition. ${ }^{8}$ The final reason for the uniqueness of the Commission in the market is the capacity of the Commission to address a variety of topics in different ways. ${ }^{9}$

The overall picture painted by Zuzana Trávníčková is a positive one. The main challenge for the Commission, according to the analysis, is the identification of public international law topics in the future. Yet, given the number of topics being proposed by the Commission, and the number of topics being placed on the long-term programme of work, identifying new topics for the Commission is unlikely to be a challenge. ${ }^{10}$

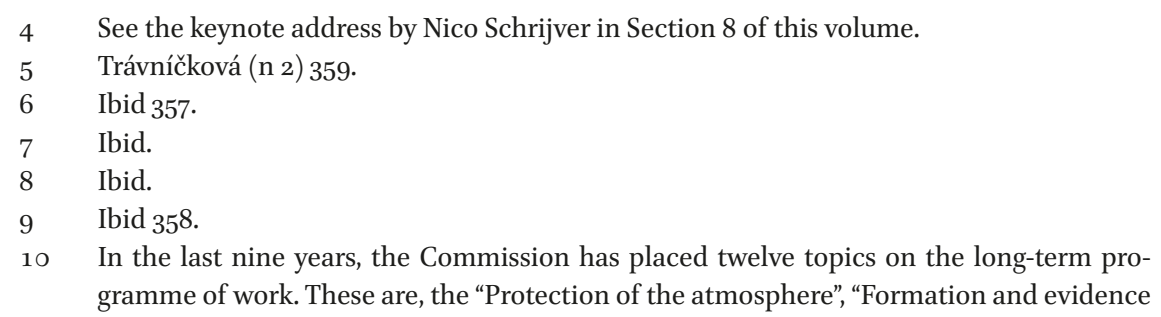


On the authority of the Commission, the paper endorses both the formal and professional authority. The formal authority is established on the basis of the Commission's creation as an organ of the General Assembly and its consequent relationship with the United Nations. Here, Zuzana Trávníčková refers to, for example, the fact that General Assembly discusses the work of the Commission and the fact that its members enjoy, in Switzerland at least, the same privileges and immunities as judges of the International Court of Justice and heads of Missions. ${ }^{11}$ None of the other service providers in the market of codification enjoy quite the same formal recognition. As to the second form of authority, the professional authority, the paper recalls that this type of authority, unlike the formal authority based on the establishment, "is not bestowed but must be earned."12 This type of authority speaks to the pedigree and quality of the Commission's work over the years, which Zuzana Trávníčková describes as "still very impressive". ${ }^{13}$ I pause here to note that the phrase "still very impressive" suggests somewhat of a dip in the professional authority, but since Zuzana Trávníčková does not make much of this, neither will I.

The second reason for the uniqueness of the Commission is its composition. Here, I dare say, Zuzana Trávníčková is somewhat defensive of the Commission's track record. She notes, with approval, that formally the Commission has lived up to the requirements for regional representation and the representation of the main forms of civilizations and of the principal legal systems of the world. And then she turns to the question of gender representation, which has been a topical one during the seventieth session of the Commission and the associated celebration. Here, she returns to the pedagogic and artistic approach, momentarily leaving the market. When her students look at the picture of the Commission on its website, she reports, they notice the gender disparity in the composition of the Commission. ${ }^{14}$ It is interesting that this particular issue is introduced and discussed in this paper, not through numbers as is often the

of customary international law" (which was subsequently renamed to "Identification of customary international law"), "The Fair and equitable treatment standard in international investments law", "Protection of the environment in relation to armed conflict"; "Provisional application of treaties"; "Settlement of disputes involving international organizations"; "Crimes against humanity"; "Jus Cogens"; "Succession of States in respect of State responsibility"; "General principles of law"; "Universal jurisdiction"; "Evidence before International Court and Tribunals"; and "Sea-level rise". In addition, several other topics, were considered (and some still are being considered) by the Commission.

11 Trávníčková (n 2) 357.

12 Ibid.

13 Ibid.

14 Ibid. 
case, ${ }^{15}$ but through imagery. At any rate, her students, at seeing this image remark, as would expected, that it is not fair that women are so underrepresented. ${ }^{16}$ There are two things that the paper does that I find interesting. The first, which I wholeheartedly agree with, is that the paper absolves the Commission from this travesty - it is I and not Zuzana Trávníčková, that describes the underrepresentation as a travesty. It is after all, not the Commission that elects members, ${ }^{17}$ nor is it the Commission that nominates members for election. It is the States. Thus, ultimately States are responsible for the travesty. The conclusion she arrives at with the students- we are unfortunately not told how this conclusion is arrived at, although I agree with it too - is that it is probably would not be helpful to amend the statute to introduce quotas for women. ${ }^{18}$

But, and this is the part of the paper that really gets me excited, Zuzana Trávníčková states that there is probably a hidden question behind this image of underrepresentation of women. That hidden question is: "Is it wrong or is it real problem that there are less women than men?"19 Her answer is interesting - and one that I do not agree with, but more on that in the conclusion. In her view "[i]t would be wrong if women were excluded [perhaps 'prohibited' is this better word] from membership. It would be wrong if the feminine attitude to international law would be something else than the masculine one ..."20 She and her students conclude that "international law knowledge of and attitude towards international law are a matter of expertise and experience, not a matter of gender and that the natural development in this question does not require any formal interference". ${ }^{21}$ In her view (and it appears that this is normally the conclusion arrived at with the class) probably the outcomes of the Commission would not have been affected had there been more women. Although the final proposal is cautious in that she suggests that "this question does not require any formal interference" 22 - suggesting that an informal

15 I myself have adopted the slogan introduced by the four women currently on the Commission - Concepción Escobar Hernández Patrícia Galvão Teles, Marja Lehto and Nilüfer Oral - seven in seventy, to describe the poor record of the Commission in this area. 16 Trávníčková (n 2) 358.

17 The exception is in cases of a casual vacancy, see article 11 of the statute of the ILC, UNGA Res 174(II) (21 November 1947) as amended by UNGA Res 485(V) (12 December 1950); Unga Res. 984(X) (3 December 1955); UNGA Res 985(X) (3 December 1955) and UNGA Res $36 / 39$ (18 November 1981).

18 Trávníčková (n 2) 258.

19 Ibid.

20 Ibid.

21 Ibid.

22 Ibid (emphasis added). 
interference may be warranted - it is telling that on the whole the suggestion seems to be that it is not a real problem. But I return to this issue in the conclusion.

Finally, a third reason for the Commission's uniqueness in the market of codification - and admittedly this reads a little bit like an afterthought - is that the Commission addresses a wide variety of topics and does so in diverse ways. The paper notes that the agenda of the Commission "since its inception has been very colourful". This statement is probably true and it is clear that in the future the Commission's choice of topic will become even more colourful. The inclusion of the topic "Sea-level rise in relation to international law" in the long-term programme of work and its likely inclusion in the agenda is testament to this fact. Of this potential, and rounding off the market analogy, $\mathrm{Zu}-$ zana Trávníčková concludes her paper by encouraging the Commission to find out "what are fashionable terms and what are real trends" in order to enhance "future market possibilities" of the Commission. ${ }^{23}$

I turn now to the very different, but equally fascinating paper of Mónica Pinto. ${ }^{24}$ This paper adopts a completely different, systematic and technical analysis of the themes under consideration - authority and members. Her paper presents numbers and statistics, not images of beautiful temples or bright or dim star. The paper does not evoke the pedagogic image of students with enquiring minds exploring, together with their Professor, the ins and outs of international law. The approach is based on hard facts and data to assess the authority of the Commission, its membership and the interaction between these two themes. It is not at all surprising that Mónica Pinto's paper comes to very different conclusions. It should also be noted that these conclusions are less sympathetic towards the Commission than those of Zuzana Trávníčková. The less sympathetic tone - and I have deliberately chosen less sympathetic instead of unsympathetic to indicate that I did not read Mónica Pinto's piece to be hostile to the Commission - is set out in the early part of the paper where low ratification of the conventions dealing with State succession prepared by the Commission is highlighted. ${ }^{25}$ Already at this stage of the paper, it is clear that the authority of the Commission ought not to be assumed. The paper reminds us that legal scholars have criticized the Commission because it has "remained in its comfort zone and avoided the changing priorities of the

23 Ibid 365 .

24 Mónica Pinto, 'The Authority and Membership of the Commission in the Future' in this Section.

Ibid 367 . 
international community". ${ }^{26}$ Although the paper immediately adopts a positive note that the "199os brought about some changes" with the work of the Commission on the elaboration of a draft statute for the International Criminal Court, this is subjected to a caveat since we are immediately referred to the less successful Convention on the Law of Non-Navigational Uses of International Watercourses. ${ }^{27}$

The paper begins by an assessment of the Commission and its composition and it paints a rather gloomy picture. First, it laments, or so it seems, the representation of different professions on the Commission. ${ }^{28}$ It notes that the main field of activity for members of the Commission is "diplomacy and legal services", ${ }^{29}$ in other words, government lawyers. There is a criticism, certainly not explicit, but veiled (perhaps implicit is the better word) that the large number of government lawyers on the Commission creates the risk that "the semi-official view"30 of members of the Commission will influence the work of the Commission. But the main observation that I draw from reading this part of the paper is the lament that "litigants, i.e. those involved mainly in international judicial activities" 31 are underrepresented. She laments that currently there are no more than three or four of such litigants. ${ }^{32}$ One point about this part of the paper is that it is different from the other parts in which the composition is considered since it does not rely on hard statistics. We are given a rough, almost thumb-suck, "three or four" as the test. Second, unlike in other sections, this "three or four", only refers to present composition whereas in the other sections, we are also given statistics about previous compositions to enable us also to draw conclusions about trends. Third, while the lament is for the lack of representation of those involved in international judicial activities, the numbers themselves only refer, it seems, to those who have served as counsel before the International Court of Justice. It seems those that may have served as counsel before arbitral tribunals or international criminal tribunals are, inexplicably, excluded. At any rate, the paper does not provide insights about how this affects the authority of the Commission or why having more litigants is a good thing, or even why "three or four" is not sufficient representation.

\begin{tabular}{ll}
\hline 26 & Ibid 267. \\
27 & Ibid. \\
28 & Ibid 369. \\
29 & Ibid. \\
30 & Ibid. \\
31 & Ibid. \\
32 & Ibid.
\end{tabular}


As with Zuzana Trávníčková's paper, the part that most intrigues me about Mónica Pinto's paper is the consideration of the gender representation. Having stated the obvious, that the members of the Commission "have been and are mostly men" the paper presents us with the stark statistical illustration of how underrepresented women are (and have been) in the Commission. ${ }^{33}$ Unlike Zuzana Trávníčková, Mónica Pinto's conclusion is unequivocal. This state of affairs is, to borrow from Trávníčková, "wrong" and is "a real problem." ${ }^{34} \mathrm{Al}-$ though she too does not suggest an amendment of the statute, she proposes that States should be encouraged to nominate women. ${ }^{35}$ Time and space do not permit me to address another of Mónica Pinto's criticism - the generational distribution. ${ }^{36}$

While Zuzana Trávníčková positively described the regional representation, Mónica Pinto digs into the numbers, to find that even here the Commission can do better. While the paper acknowledges that the regional representation on the Commission is generally acceptable, she notes that this does not translate into the appointment of Special Rapporteurs. ${ }^{37}$ The figures are incredible, if unsurprising. Out of a total of 61 Special Rapporteurs between 1949 and 2016, more than half come from Western Europe and Others, 9 from Eastern Europe, 9 from Latin America and the Caribbean, 7 from Africa and 5 from Asia. ${ }^{38}$ The paper drills further into the numbers of Special Rapporteurs, but the big take away is that there is a disproportionate imbalance in favour of "white males, generally from common law countries, nearly always from North America and Europe". ${ }^{39}$ This, she warns, needs to change to reflect an international community "that has become increasingly multicultural and diverse." 40

These two wonderful papers address many more issues, including choice of topics and products. I however, have limited this discussion to those issues that directly impact on both themes - membership and authority.

I turn now to offer a few concluding remarks.

Ibid. For the current Commission, women represent a measly 11.75 per cent while between 2002 and 2010, only two women, Paula Escarameia and Hanqin Xue, served on the Commission, signifying an underwhelming 5.88 per cent representation. Trávníčková (n 2 ) 358.

35 Pinto (n 25) 370.

36 Here, she notes that "the average age of the members is around 55 years old, with individual ages ranging from 35 years to 82 years." Ibid.

37 Ibid.

38 Ibid 370-371.

39 Ibid 371.

40 Ibid. 


\section{Concluding Remarks}

The fact that these two papers look at the same institution, looking at the same materials, in such different ways, and manage to come to such starkly different conclusions tells us so much. First, and I think for me most important, is that there is strength in diversity and diverse approaches. A cursory survey of the profiles of members of the Commission reveals that substantively and geographically, this is the case with the composition of the Commission - I return to gender momentarily. This diversity is borne out also by a study of the summary records of the Commission, where members of the Commission often display fundamental differences to their approach to international law and its codification and progressive development. ${ }^{41}$

The second point I wish to make is that while the papers use different analytical techniques and come to vastly different conclusions, there is a complementarity between them. To illustrate this point, I focus on gender representation since it is here that the two authors arrive at the most divergent conclusions. To take the Zuzana Trávníčková's paper, while I like the search for beauty implicit in a literary approach (and I wish it had been more dominant than the market analogy in the rest of the written paper), the truth is that beauty is in the eye of the beholder. So, while we can never have the answer to the hidden question of whether a more equitable representation would have affected the outcomes of the work of the Commission, surely there is value in diversity itself. Moreover, having experienced two versions of the Commission, I can attest that the presence of women has had an impact. I have served with five out of the seven women that have been on the Commission. All of them are nationals of States belonging to the Western European and Others Group. It is interesting that all five, including Marie Jacobsson who is no longer on the Commission, have supported exceptions to immunity while only one male counterpart from the Western European and Others Group has supported such exceptions - leaving the vast majority of its male representatives opposing exceptions to immunity. ${ }^{42}$ I could apply this test to the question of "fundamental values" as characteristic of norms of jus cogens and come to the same conclusion. I should not be misunderstood. I do not suggest that they hold this position because they are women. I only wish to point to the risks in suggesting that having more women on the Commission would have had

\footnotetext{
41 If I can express a slight concern, it is that sometimes, some members express adopt the approach their view is not only the best approach, but the only approach, illustrated by the description of the views of others as "wrong". 
no impact on the substance of the Commission's work. Similarly, on Mónica Pinto's paper, it is the case that statistics tell us a lot, but they also hide a lot, do they not? On gender distribution it is definitely true that women are inadequately represented - I would say unacceptably so - on the Commission. But if one looked at the statistics in a different way, one might see that there is a gradual improvement. Before 2002, there had been zero women. Now we have had seven. Between 2002 and 2010, women made up only 5.88 per cent of the Commission. They currently make up just over 11 per cent. While this number remains indecent, it is hard not to observe an improvement. Again, this should not be seen as a pat on the collective back of States for getting the number to the underwhelming 11 per cent, but simply a recognition of the empirical fact of change (I had wanted to say progress but that might be going too far).

In sum, like the Commission, I think these papers remind us that diversity in approaches, perspectives and views should be embraced. 